\title{
KINEMATIC MODEL OF ACTIVE DEFORMATION IN CENTRAL ASIA
}

\author{
Jean-Philippe Avouac \\ Laboratoire de Détection Géophysique, CEA, Bruyères-le-Châtel, France
}

\author{
Paul Tapponnier \\ Laboratoire de Tectonique, IPGP, Paris, France
}

\begin{abstract}
The velocity field of present-day deformation in Central Asia is modelled using a set of four rotating blocks (Siberia, Tarim, Tibet, India) on a spherical earth. A best-fit is inverted on the basis of estimated shorteningrates across the main thrust zones (Himalayas, Tien Shan) and measured slip-rates along the principal strike-slip faults (Altyn Tagh and Karakorum) separating those blocks. The fit to the data implies that nearly all the present convergence between India and Asia can be accounted for by slip-partitioning on these four zones, with as much as $50 \%$ absorbed by northeastwards extrusion of Tibet. This suggests that localised deformation governs the present mechanical behaviour of the Central Asian lithosphere.
\end{abstract}

\section{Introduction}

Quaternary faulting and seismicity show that most of the active deformation of Central Asia is partitionned between thrusting in mountain belts and sliding along great strikeslip faults (Figure 1), [Tapponnier and Molnar, 1977, 1979]. The strike-slip fault pattern has long been interpreted to rcsult from extrusion due to the indentation of India into Asia [Tapponnier and Molnar, 1976]. The pattern is asymmetric, indicative of an eastward component in the extrusion of Tibet [Tapponnier et al., 1986; Armijo et al, 1986, 1989]. Such asymmetric extrusion is observed in all laboratory experiments where strain-softening materials are used and where a free-boundary is taken to represent the southeastern, active margin of Asia, whether in plane-strain [Peltzer and Tapponnier, 1988], or under dynamically scaled conditions in 3D [Peltzer, 1988; Davy and Cobbold, 1988]. By contrast, scaled numerical simulations on laterally-confined viscous fluids have been interpreted to imply an overwhelming predominance of crustal thickening, thus casting doubt on the existence of extrusion [England and Houseman, 1986].

The controversy has endured because a quantitative description of the natural strain field induced by continental collision in Asia was missing. Using new measurements of slip-rates on the main fault-zones of Central Asia, we propose here such a description, based on a block model constrained by inversion, that helps assess the importance of extrusion.

\section{Deformation Zones and Rates}

Three main zoncs of active strain divide Central Asia into four principal blocks. Kazakhstan and Dzungaria, both attached to Siberia, are separated from the Tarim by the actively rising Tien Shan mountain range (Figure 1). The westward widening of that range reflects a westward increase of the amount of shortening, and of the presentday shortening rates and seismicity. This increase can be quantitatively accounted for by clockwise rotation of the Tarim relative to Siberia, about a pole located near the

Copyright 1993 by the American Geophysical Union. eastern extremity of the range at $95.7^{\circ} \mathrm{E}, 43.5^{\circ} \mathrm{N}$ [Avouac et al, 1991, 1992], in agreement with paleomagnetic evidence [Chen et al., 1991]. The geologically estimated shortening-rate in the eastern Tien Shan, $6 \pm 3 \mathrm{~mm} / \mathrm{yr}$ [Avouac et al., 1992], at a distance of about $750 \mathrm{~km}$ from the pole, is thus compatible with the centennial seismic shortening rate, averaged along the whole range, 13 $\pm 7 \mathrm{~mm} / \mathrm{yr}$ [Molnar and Deng, 1984].

The low level of seismicity south of the Tien Shan implies that the Tarim block (Figure 1), a strong Precambrian craton, suffers negligible strain. Over a length of $2000 \mathrm{~km}$, the left-lateral Altyn Tagh Fault, largest strike-slip fault of Asia, separates the Tarim from Tibet [Tapponnier and Molnar, 1977]. Between $81^{\circ}$ and $97^{\circ} \mathrm{E}$, this fault keeps a strike of $\approx \mathrm{N} 80^{\circ} \mathrm{E}$. From the offsets of post-glacial morphological features visible on panchromatic SPOT images, Peltzer et al. [1989] deduced an average Holocene slip-rate of $\approx 30 \mathrm{~mm} / \mathrm{yr}$ along the central stretch of the fault. To the east, the rate decreases to $\approx 5 \mathrm{~mm} / \mathrm{yr}$ near $96^{\circ} \mathrm{E}$, as motion becomes transferred to oblique splaythrusts in the eastern Kunlun, Qaidam and Qilian Shan [Peltzer et al., 1988, 1989; Meyer, 1991; Tapponnier et al., 1990]. West of $81^{\circ} \mathrm{E}$, the fault bends to $\mathrm{N} 100^{\circ} \mathrm{E}$ for $400 \mathrm{~km}$ along the Yurungkax and Karakax valleys (Figure 1), where the Holocene slip-rate first inferred with SPOT by Peltzer et al. [1989] from offsets now mapped and measured in the field [Avouac, 1991] is $\approx 20 \mathrm{~mm} / \mathrm{yr}$.

Present-day deformation within the Tibetan plateau involves mostly strike-slip faulting and E-W extension [Armijo et al, 1986; Molnar and Lyon-Caen, 1989]. The principal strike-slip faults lie near the southern edge of the plateau, along the dextral Karakorum-Jiali Fault Zone (KJFZ) [Armijo et al., 1989], (Figure 1). From offset postglacial morphological markers mapped in the field, Armijo et al [1989] deduced a Holocene slip-rate of $15 \pm 7 \mathrm{~mm} / \mathrm{yr}$ along that zone east of $88^{\circ} \mathrm{E}$. From similar markers in the field and on SPOT images, Liu et al. [1991] determined a Holocene slip rate of $\approx 32 \mathrm{~mm} / \mathrm{yr}$ on the rightlateral Karakorum fault west of $80^{\circ} \mathrm{E}$. Between the Altyn Tagh fault and KJFZ, present day strain within central Tibet is moderate [Armijo et al., 1986, 1989]. West of $85^{\circ} \mathrm{E}$, most of it occurs along the Longmu-Gozha Co fault, a left-lateral splay of the Altyn Tagh [Peltzer et al., 1989], [Figure 1), along which Holocene left-lateral movement was recently confirmed in the field [Liu et al., 1991].

South of KJFZ, southern Tibet is the site of active, N-S normal faulting (Figure 1). By relating the corresponding Holocene extension rate $(10 \pm 5 \mathrm{~mm} / \mathrm{yr})$ to divergent overthrusting along the Himalayan arc, Armijo et al. [1986] have obtained a Holocene shortening rate of $20 \pm 10 \mathrm{~mm} / \mathrm{yr}$ in the Himalayas. This estimate is consistent with the centennial seismic shortening rate $(18 \mathrm{~mm} / \mathrm{yr})$ [Molnar and Deng, 1984] and with the rate derived from Late Cenozoic sedimentation in the Ganges flexural basin $(18 \pm 7 \mathrm{~mm} / \mathrm{yr})$ [Molnar and Lyon-Caen, 1989]. South of the Himalayas, the minor seismicity and low topography imply that the strong Indian Precambrian craton behaves, like the Tarim, as a relatively rigid block.

\section{Modelling and Results}

We take the simplified map of Figure 2 as a basis for 


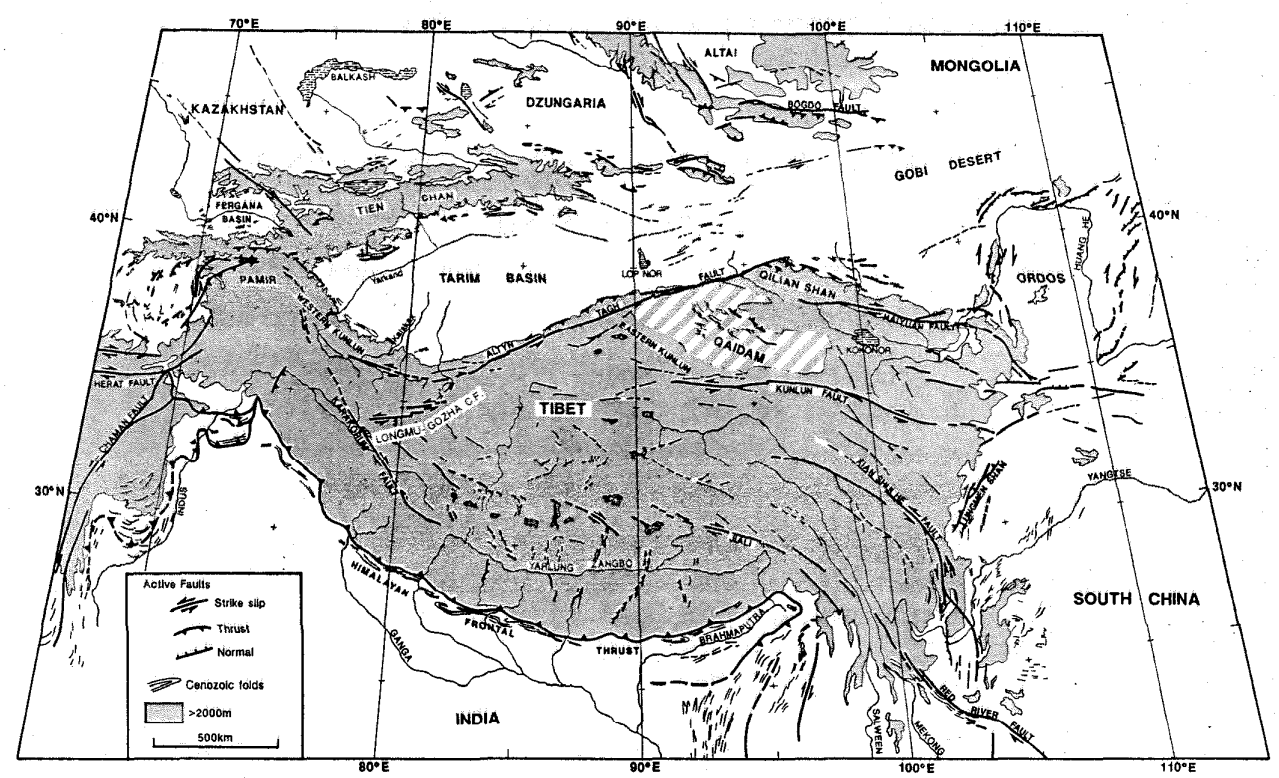

Figure 1: Map of active tectonics of central Asia, modified from Tapponnier and Molnar [1977, 1979] and Armijo et al. [1986, 1989], [Avouac et al., 1991].

kinematic modelling. As that of Armijo et al. [1989], our model involves four undeforming, rotating blocks (Siberia, Tarim, Tibet, India). The Tien Shan thrusts are represented by a great circle arc following the middle of the range. The Longmu-Gozha Co fault, southern splay of the Altyn Tagh, is neglected. Distributed extension in southern Tibet, rightlateral slip along $\mathrm{KJFZ}$ and thrusting in the Himalayas, are taken to result from crustal partitioning of deep oblique movement between central Tibet and India along a single lithospheric interface following the Himalayan arc. That arc is divided into three segments with different shortening azimuths. The strike-slip rates on Figure 2 and Table 1, with their $1-\sigma$ uncertainties ( $65 \%$ confidence intervals), are derived from the data of Peltzer et al. [1989] and Liu et al. [1991] by averaging individual offset measurements, assuming that their ages vary between 8 and $12 \mathrm{ka}$, most likely age-range of deglaciation in Tibet [Gasse et al., 1991]. Although well constrained, the $19 \pm 3 \mathrm{~mm} / \mathrm{yr}$ sliprate in the Karakax valley underestimates the total strikeslip motion between Tibet and Tarim, because slip on the Longmu-Gozha Co fault is neglected. This rate is therefore ascribed a large, arbitrary uncertainty of $20 \mathrm{~mm} / \mathrm{yr}$ (Table 1).

The kinematics of the model are defined by the Euler vectors describing the motions of the three mobile blocks relative to Siberia. We sought the model for best-fit of the data set of Table 1, according to a standard inversion procedure. A priori constraints are taken to be the most secure parameters describing rigid block-motion in Central Asia, namely the Nuvel-1 Euler vector of the movement of India with relative to Siberia [DeMets et al., 1990] and the position of the pole of rotation of the Tarim relative to Siberia [Avouac et al., 1991, 1992]. As in global plate kinematic models [Minster and Jordan, 1978; DeMets et al., 1990], the inversion is done by minimizing weighted least-squares errors:

$$
\mathrm{E}=\Sigma_{\mathrm{i}=1, \mathrm{~N}}\left[\left(\mathrm{R}_{\mathrm{obs}} \mathrm{R}^{\mathrm{pred}}{ }_{\mathrm{i}}\right) / \sigma_{\mathrm{i}}\right]^{2}
$$

where $\mathrm{N}$ is the total number of data, $\mathrm{R}^{\mathrm{obs}}$ is the ith rate in the data set (Table 1$), \sigma_{\mathrm{i}}$ is the standard error assigned to this datum, and $\mathrm{R}^{\text {pred }}{ }_{i}$ is ith rate predicted from the model parameters. Our best-fitting model predicts slip rates that fit the data within less than $6 \mathrm{~mm} / \mathrm{yr}$, with a small total error, Emin, of 0.36 (Table 1). For each model parameter, the $65 \%$ confidence interval is that within which $\mathrm{E}<\mathrm{Emin}+1$ [Press et al., 1986]. Our total error is much smaller than that in the block model of Armijo et al. [1989], (9.2, Table
1), because that first model was based on Minster and Jordan's [1978] RM2 In/As Euler vector and lacked the new slip-rates estimates on the Altyn Tagh and Karakorum faults and constraint on the $\mathrm{Ta} / \mathrm{Si}$ pole.

The main features of our model are shown on Figure 3 and Table 2. In the Siberian reference frame, the Tarim rotates clockwise about the pole at $43.5^{\circ} \mathrm{N}, 95.7^{\circ} \mathrm{E}$, at a rate of $0.65 \pm 0.30^{\circ} / \mathrm{Ma}$. Tibet rotates counterclockwise about a pole at $44.2+5^{\circ} \mathrm{N}, 64.4 \pm 12^{\circ} \mathrm{E}$, at a rate of $0.89 \pm 0.35 \% / \mathrm{Ma}$. The $65 \%$ confidence ellipse of the latter pole (comprising all pole positions for which $\mathrm{E}<$ Emin +2.7 [Press et al., 1986]) is centered at $44.5^{\circ} \mathrm{N}$, $52^{\circ} \mathrm{E}$, with a semi-major axis of $15^{\circ}$ in the direction $\mathrm{N} 103^{\circ} \mathrm{E}$ and a semi-minor axis of $5^{\circ}$. Our model confirms the existence of an eastward component of motion of central Tibet relative to either Siberia or India (extrusion). In the Siberian reference frame, Tibet's present-day rate of motion at $33^{\circ} \mathrm{N}, 90.5^{\circ} \mathrm{E}$ is $40 \mathrm{~mm} / \mathrm{yr}$ northeastwards, absorbing $50 \%$ of the convergence between India and Siberia, 20\% more than inferred by Armijo et al. [1989]. The In/Si convergence predicted by Nuvel-1, whose direction is $20^{\circ}$ clockwise of that of RM2 [DeMets et al., Figure 48, 1990] thus creates more rapid extrusion than $\mathrm{RM} 2$, given our assumptions.

\section{Consequences}

Although slip-data on the more numerous active faults of eastern Tibet and China is insufficient to constrain the

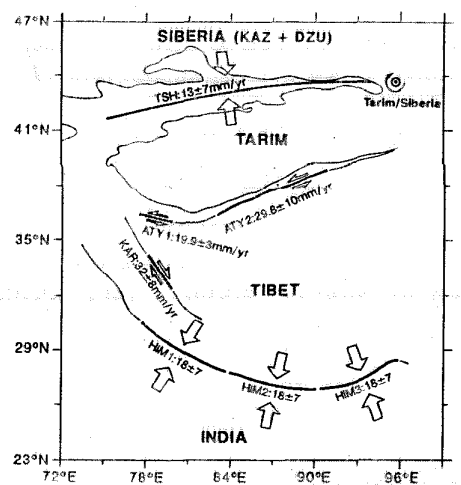

Fig. 2. simplified map of active fault zones and slip rates taken into account for kinematic inversion. 
TABLE 1. Estimated and Predicted Slip-Rates on Faults of Figures 1 and 2.

\begin{tabular}{|c|c|c|c|c|c|c|c|}
\hline Datum & \multicolumn{2}{|c|}{ Obs. Rates (mm/a) } & \multicolumn{2}{|c|}{$\begin{array}{l}\text { Pred. Rates (mm/a) } \\
\text { [Armijo et al, 1989] }\end{array}$} & \multicolumn{2}{|c|}{$\begin{array}{c}\text { Pred. Rates (mm/a) } \\
\text { (this study) }\end{array}$} & \multirow{2}{*}{$\begin{array}{c}\text { Contribution (\%) } \\
\begin{array}{l}2.3 \\
9.1\end{array}\end{array}$} \\
\hline $\begin{array}{l}\text { Aty1 } \\
\text { Aty2 }\end{array}$ & $\begin{array}{l}19.9^{\prime \prime} \pm 20 . \\
29.8 \pm 10 .\end{array}$ & $\perp$ & $\begin{array}{l}11 \\
22.8 \\
31.0\end{array}$ & $\begin{array}{l}\frac{1}{-22.3} \\
-0.9\end{array}$ & $\begin{array}{l}11 \\
24.6 \\
27.2\end{array}$ & $\begin{array}{l}1 \\
-7.9 \\
-13.5\end{array}$ & \\
\hline Kar & $-32.0 \pm 8.0$ & & -13 & -9.4 & -31.2 & -8.1 & 14.2 \\
\hline $\begin{array}{l}\operatorname{Him1} 1 \\
\text { Him2 } \\
\text { Him3 }\end{array}$ & & $\begin{array}{l}-18.0 \pm 7.0 \\
-18.0 \pm 7.0 \\
-18.0 \pm 7.0\end{array}$ & $\begin{array}{r}-5.1 \\
3.5 \\
13.2\end{array}$ & $\begin{array}{l}-16.7 \\
-25.0 \\
-28.4\end{array}$ & $\begin{array}{l}-29.5 \\
-21.8 \\
-12.8\end{array}$ & $\begin{array}{l}-15.2 \\
-19.6 \\
-18.8\end{array}$ & $\begin{array}{l}18.6 \\
18.6 \\
18.6\end{array}$ \\
\hline Tsh & & $-13.0 \pm 7.0$ & 10.2 & -17.1 & 0.0 & -12.6 & 18.6 \\
\hline Tota & rr: & & & 2 & & 36 & \\
\hline
\end{tabular}

TABLE 2. Euler Vectors Defining Best-Fitting Model.

\begin{tabular}{llll}
\hline Block & Lat. $\left({ }^{\circ} \mathrm{N}\right)$ & Long. $\left({ }^{\circ} \mathrm{E}\right)$ & $\omega\left({ }^{\circ} / \mathrm{Ma}\right)$ \\
\hline Tarim & 43.5 & 95.7 & $-0.65 \pm 0.3$ \\
Tibet & $44.2 \pm 5$ & $64.4 \pm 12$ & $0.89 \pm 0.35$ \\
India & 24.6 & 17.7 & 0.53 \\
\hline
\end{tabular}

Counter-clockwise rotations in Siberian reference frame are taken to be positive. Uncertainties correspond to $65 \%$ confidence intervals derived from data uncertainties. A priori constrained parameters are italicized.

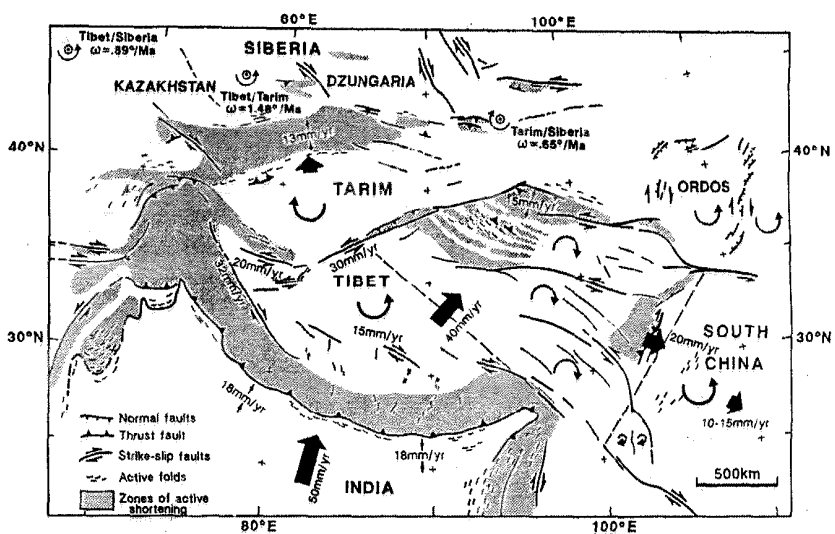

Fig. 3. Best fitting Kinematic model of active deformation in central Asia derived from inversion, with four blocks model of figure 2, of data in table 1. Euler poles describing motions of Tibet and Tarim relative to Siberia, of Tibet relative to Tarim, and senses and rates of rotation and motion are shown. Large open arrows indicate major block motions in Siberian reference frame. Senses and values east of $95^{\circ} \mathrm{E}$ are not constrained by inversion.

kinematics of present-day movements in regions east of $95^{\circ} \mathrm{E}$, several consequences of our model are worth discussing (Figure 3). Crustal thickening in the QaidamQilian Shan must absorb only a fraction of Tibet's motion [Meyer, 1991; Tapponnier et al, 1990], (Figures 1 and 3), lest these mountains be greater and more seismically active than the Himalayas. With $\approx 15 \mathrm{~mm} / \mathrm{yr}$ of shortening converted into crustal thickening in those mountains [Meyer, 1991], the remaining motion probably causes southeastward displacement of SE-Tibet's edge at $\approx 20 \mathrm{~mm} / \mathrm{yr}$ (Figure 3 ) by a transfer mechanism involving escape and clockwise rotation of the curved blocks separated by the left-lateral Kunlun and Xianshui He strikeslip faults (Figure 4). This is because such faulting, a no surface-change process, changes the direction of extrusion (Figure 4a), rather than its amount [England and Molnar, 1990]. In addition, the similar curvature of the faults [Molnar and Lyon-Caen, 1989], (Figure 4b) permits accomodation of differential block rotation, which leads to southward increase in the amount of extrusion and rate of

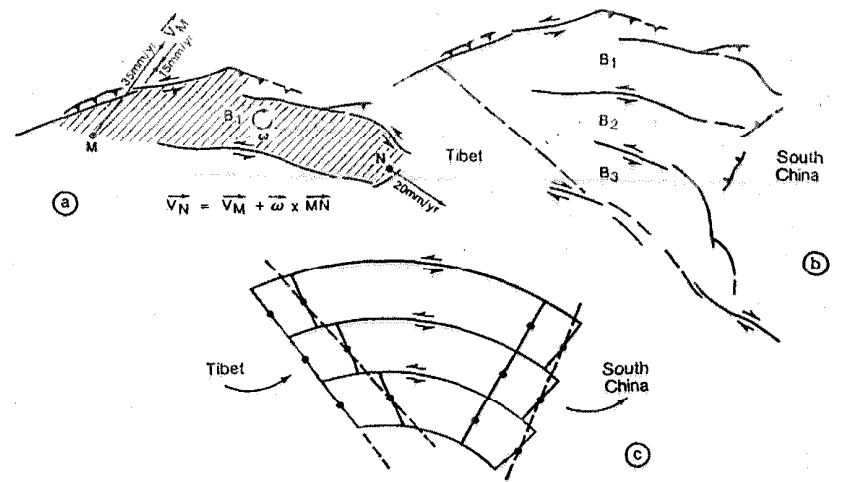

Fig. 4. Simplified kinematic model of extrusion transfer from Tibet to South China, across Qinghai and Sichuan, by rotation and escape (a) of blocks separated by left-lateral strike-slip faults with similar curvature (b). Counterclockwise rotation of South China is predicted (c).
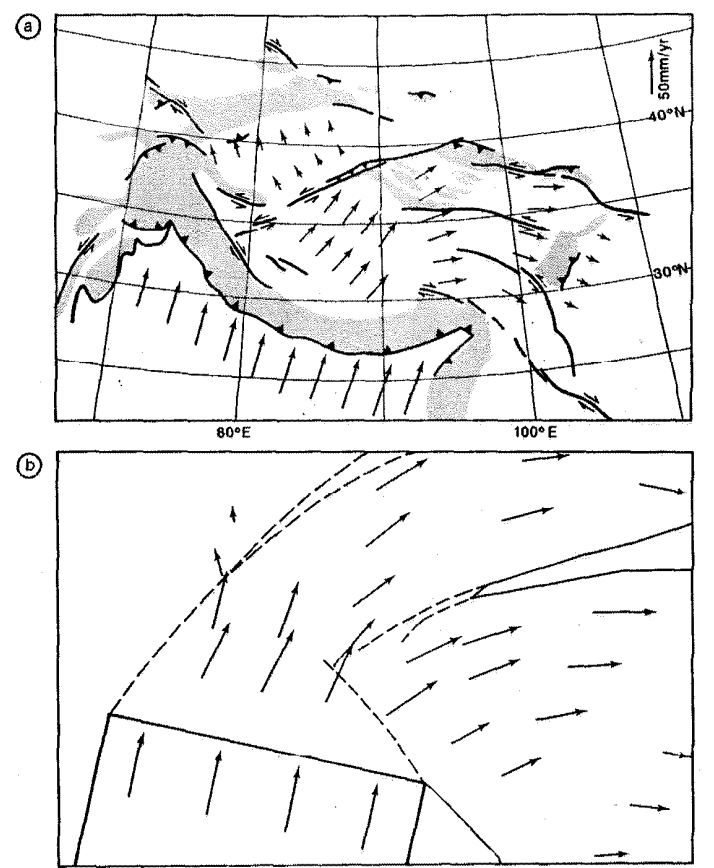

Fig. 5. Velocity field, relative to Siberia, derived from best-fitting four-block model (a). Comparison with typical velocity field of plane-strain indentation of plasticine block with free boundary on right side, after Peltzer and Tapponnier [1988] (b).

rotation (Figure $4 \mathrm{c}$ ). Since thrusting along the Lungmen Shan, a range smaller than the Tien Shan, with a poorly developed Cenozoic foreland basin, is unlikely to absorb more than $10 \mathrm{~mm} / \mathrm{yr}$ of shortening, South China probably 
moves southeastwards at a minimum rate of $\approx 10-15 \mathrm{~mm} / \mathrm{yr}$ relative to Siberia (Figure 3). If the shortening gradient along the Lungmen Shan were small, the transfer mechanism of figure 4 predicts that South China might also rotate clockwise, as may the Ordos and adjacent North Chinese blocks [Peltzer and Tapponnier, 1988).

The fit between estimated and predicted slip-rates implies that our block model provides, within $\approx 10 \%$, an adequate quantitative description of present strain in central Asia. Apparently, movement along the fault-zones separating the blocks suffices to account for nearly all the convergence between India and Western Siberia. The velocity field derived from the model (Figure 5a) is asymmetric, with curved, dominant motions towards the East and changes in velocity directions resembling those observed in unilaterally confined indentation experiments (Figure 5b). It reflects rather fast extrusion towards Asia's SE edge along strike-slip faults, implying that strain localisation on them and moderate horizontal stress across that edge govern the mechanical behaviour of the Asian lithosphere [Peltzer and Tapponnier, 1988].

Ackowledgments. We acknowledge support from DBT, IST, INSU and CNRS.

\section{References}

Armijo, R., P. Tapponnier, J.L. Mercier, and H. Tonglin, Quaternary extension in Southern Tibet, J. Geophys. Res., 91, 13803-13872, 1986.

Armijo, R., P. Tapponnier, H. Tonglin, Late Cenozoic right-lateral strike-slip faulting in Southern Tibet, $\underline{\mathrm{J}}$ Geophys. Res., 94, 2787-2838, 1989.

Avouac, J.P., Application des méthodes de morphologie quantitative à la néotectonique, Modèle cinématique des déformations actives en Asie Centrale, doctorat, Univ. Paris VII, 156 pp., 1991.

Avouac, J.P., Tapponnier, M. Bai, H. You, and G. Wang, Active faulting and folding in the northern Tien Shan and rotation of Tarim relative to Dzungaria and Kazakhstan, J. Geophys. Res., 1993.

Chen, Y., J. P. Cogne, V. Courtillot, J. P. Avouac, P. Tapponnier, E. Buffetaut, G. Wang, M. Bai, H. You, M. Li and C. Wei, Paeomagnetic study of Mesozoic continental sediments along the northern Tien Shan (China) and heterogeneous strain in Central Asia, J.Geophys. Res., 96, 4065-4082, 1991.

Davy,P. and P.R. Cobbold, Indentation tectonics in nature and experiments, 1, Central Asia, Bull. Geol. Inst. Uppsala, 14, 129-142, 1988.

DeMets, C., R.G. Gordon, D.F. Argus, and S Stein, Current Plate Motion, Geophys. J. Int., 101, 425-478, 1990.

England, P., and G. Houseman, Finite strain calculation of continental deformation, 2, Comparison with the IndiaAsia collision zone. J. Geophys. Res. 91. 3664-3676, 1986.

England, P., and P. Molnar, Right-lateral shear and rotation as the explanation for strike-slip in eastern Tibet, Nature, 344, 140-142, 1990.

Gasse, F., M. Arnold, J. Ch. Fontes, M. Fort, E. Gibert, A. Huc, Y. Li, Q. Liu, F. Melères, E. Van Campo, F. Wang, and Q. Zheng, A 13,000 yr climatic record in western Tibet, Nature, Nature, 353, 742-745, 1991.

Liu Qing, J.P. Avouac, P. Tapponnier and Q. Zhang,
Field evidence for Holocene and active faulting in western Qangtang, Terra Abstracts, 3, 1, E.U.G. S1525, p. 265,1991 .

Liu Qing, J.P. Avouac, P. Tapponnier, and Q. Zhang, Holocene movement along the southern part of the Karakorum fault, Int. Symposium on the Karakorum and Kunlun mountains, Kashgar, China, 91, 1992.

Meyer, B., Mécanismes des grands tremblements de terre et du raccourcissement crustal oblique au bord nord-est du Tibet, doctorat, Univ. Paris VI, 129 pp, 1991.

Minster, J.B. and T.H. Jordan, Present-day plate motions, J. Geophys. Res., 83, 5331-5354, 1978.

Molnar, P., and Q. Deng, Faulting associated with large earthquakes and the average rate of deformation in central and eastern Asia, J. Geophys. Res., 89, 62036228, 1984.

Molnar, P., and H. Lyon-Caen, Faults plane solution of earthquakes and active tectonics of the Tibetan Plateau and its margins, Geophys. J. Int., 99, 123-153, 1989.

Peltzer, G., P. Tapponnier, Y. Gaudemer, B. Meyer, S. Guo, K. Yin,C. Chen and H. Dai, Offsets of late Quaternary morphology, rate of slip and recurrence of large earthquake on the Chang Ma Fault, J. Geophys. Res., 93, 7793-7812, 1988.

Peltzer, G., and P. Tapponnier, Formation and evolution of strike-slip faults, rifts and basins during the India Asia collision: an experimental approach, J. Geophys. Res., 93, 15095-15117, 1988.

Peltzer G., Centrifuge experiments of continental scale tectonics in Asia, Bull. Geol. Inst. Univ. Uppsala, 14, 115-128, 1988.

Peltzer, G., P. Tapponnier and R. Armijo, Magnitude of Late Quaternary left-lateral displacements along the north edge of Tibet, Science, 246,1285-1289, 1989.

Press W. H., B.P. Flannery, S. A. Teukolsky and W.T. Vetterling., Numerical recipes, Cambridge university Press, Cambridge, 1986.

Tapponnier, P., and P. Molnar, Slip-line field theory and large-scale continental tectonics, Nature, 264, 319-324, 1976.

Tapponnier, P.and P. Molnar, Active Faulting and tectonics of China, J. Geophys. Res., 82, 2905, 2930, 1977.

Tapponnier, P. and P. Molnar, Active faulting and cenozoic tectonics of the Tien Shan, Mongolia and Baykal regions, J. Geophys. Res., 84, 3425-3459, 1979.

Tapponnier, P., B. Meyer, J.P. Avouac, G. Peltzer, Y. Gaudemer, G. Shunmin, X. Hongfa, Y. Kelun, C. Zhitai, C. Shuahua, and D. Huagang, Active thrusting and folding in the Qilian Shan, and decoupling between upper crust and mantle in northeastern Tibet, Earth Planet. Sci. Lett., 97, 382-403, 1990.

Jean-Philippe Avouac, Laboratoire de Détection Géophysique, CEA, BP 12, 91680 Bruyères-le-Châtel, France.

Paul Tapponnier, Laboratoire de Tectonique, Institut de Physique du Globe, 4. place Jussieu, 75252 Paris Cedex 0.5 . France.

(received December 17, 1992; accepted January $7,1993$. 